\title{
INCREMENTS IN NAVAJO CONVERSATION
}

\author{
Margaret Field
}

\begin{abstract}
This paper examines the use of increments (Schegloff 1996, Ford et al. 2002) in naturally occurring Navajo discourse (conversation.) Navajo is a polysynthetic verb-final language belonging to the Athabascan family, spoken in the American Southwest. It finds that Navajo increments, specifically "glue-ons" (Couper-Kuhlen \& Ono this volume) appear in the form of temporal or locative adverbial phrases as well as unattached NPs, as is the case in English and other languages. However, Navajo increments do not appear to serve two functions suggested by Ford et al.(2002) for increments in English: "pursuing uptake" in the case of lack of recipiency, and the indexing of a "stance display" toward the speaker's own previous utterance. This is not surprising given other cultural differences in Athabaskan interaction which revolve around a value on individual autonomy, with important consequences for language use.
\end{abstract}

Keywords: American Indian Interaction; American Indian Discourse; Navajo; American Indian pragmatics.

\section{Introduction}

This paper examines the use of a pragmatic unit which has been called an increment (Schegloff 2000; Ford et al 2002; Couper-Kuhlen \& Ono, this volume), as it functions in Navajo conversation. As defined by Ford \& Thompson (1996), increments can be described as "constituents that are added to turns which, at a just prior point, are interpretable as possibly complete syntactically and prosodically, and as possibly complete actions in a local interactional sequence." In particular, three of the examples found consist of what Couper-Kuhlen \& Ono (this volume) term "'glue-ons;" i.e., increments which are "grammatically fitted to the end of the host," and one is a pragmatic extension of a turn which is otherwise complete in every way (in CouperKuhlen \& Ono's typology, a "free constituent.") My findings include the observation that some of the same grammatical forms found in English increments, (specifically in glue-ons, in Couper-Kuhlen and Ono's typology,) are also found in Navajo, including adverbial (especially temporal) phrases and locative deictics. However, I did not find some other commonly occurring forms of increments in English, including reason clauses and relative clauses. In written Navajo, subordinated verbs and clauses such as reason clauses and relativized verbs precede main clauses, which may also be the case in much spoken discourse, and may be why I found no examples of these subordinate clauses in conversation. Another common type of English increment which I found only 


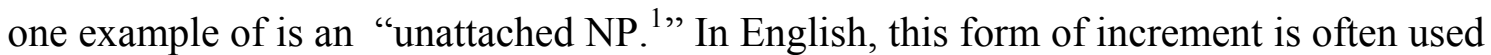
for assessment (Ford et al. 2002). In Navajo, however, it is stative verbs which perform the function of assessment. Using stative verbs to accomplish assessment means that they stand as a separate clause, and are not grammatically dependent, which is part of Couper-Kuhlen and Ono's definition of "glue-on" increments.In addition, the function of increments in Navajo is different from that of English usage. For example, they do not appear to be used to elicit uptake from the hearer, nor for the purpose of assessments or "stance displays" toward the speaker's own previous (host) utterance (Ford et al 2002). Finally, the prosody of Navajo increments is also different from that attributed to some English increments ("rush-throughs") in Schegloff 1996 and Ford \& Thompson 1996 , in that they are not rushed in any way.

I found four examples in a single 20 minute long conversation between two 40 year-old men whose first language is Navajo ${ }^{2}$. This conversation took place in the University of New Mexico library in 1996. Both of the speakers ("T" and "E") were college students at the time. The transcription system used is Du Bois et al $1993^{3}$.

\section{Data}

\section{Example 1}

Referring to the host of a healing ceremony (on the Navajo reservation) which $\mathrm{T}$ has just returned from:

1T:

$$
\text { ...(1) eilá }
$$

that one,

2

bima yik'inahasá.

3.poss-mother over-3p-walk.circle.perf.

he performed the ceremony for his mom.

3E: $\quad \ldots$ aah.

4T: $\rightarrow \quad \ldots(1)$ áájí.

remote-deic.

over there

5

... k'adęę,

almost $=$,

${ }^{1}$ A type of increment which consists of lone nouns with "no possibility of syntactic integration" (Ford et al. 2002).

${ }^{2}$ Unfortunately, these are the only examples in the transcripts of Navajo conversation which are available to me. Although obviously Navajo grammar is no more "exotic" than any other human language, it seems comparably exotic in a discussion of interaction and grammar. This is because it has only recently become a written language, and as very few people are able to transcribe spoken Navajo, no other corpus of Navajo conversation exists, to my knowledge.

${ }^{3}$ Cf. appendix. 
6 neeznago 'oołkiłgo shii, ten o'clock.being almost, ...(2) ch'ínijeeh. out-pl.move we got out.

$8 \mathrm{E}:$ ...(1) ńleidi. over there.

10T: $\quad\left[\mathrm{aoo}={ }^{\prime}\right]$. yes.

$11 \quad$...(1) akondi t'aa hoozk'azíyęę but (it was) just cool then,

In this example a deictic term consisting of a remote stem áá- and the postposition -jí are added on following a turn-constructional unit (TCU) which is otherwise grammatically, pragmatically, and intonationally complete. This term may also be translated colloquially as "on the reservation" or "on the other side." This example is not very different from English examples involving the use of prepositional phrases or locative adverbials as "glue-ons."

The next example is also similar to the English usage of increments, consisting of a temporal adverbial clause which is added on following a turn which is otherwise complete in every way; however, it differs from the English usage of temporal adverbials (which typically begin with while or when) in that the morphology which marks it as a subordinate clause (a "glue-on") must come at the end of the utterance, not the beginning.

\section{Example 2}

1T: hai baa i'í' ná'ah last weekyéę? who for $2 \mathrm{p}$-drop.ballot

who did you vote for last week?

2E: $\quad$...(1) éí t'áá níléí absentee-ballotigíí. just that absentee ballot-one.

3T: $\quad$ aoo', éídi, éídi, éídi, yes, that one, that one, that one.

4 ... Bízhánee' ...(1) t’áá t'óó ‘anó beezhí $\mathrm{BC} / \mathrm{BD}^{4}$.

... Lucky (them) just simply being called BC/BD.

\footnotetext{
${ }^{4}$ E.g.: Bill Clinton/Bob Dole.
} 
$5 \quad . . .(1)$ [@@@ ...(BREATH)

6E: [@@@]

7T: ... (3) éí hastiin 'ábíjaah dadikaadigíi baa'it'íshaał nisingo. that guy thus-3p-ear are.flat-rel for-1p-vote.fut $1 p$-think-sub I'm going to vote for the guy whose ears are big (and) flappy, I think.

8E: $\quad . .(1) @ @ . . H e=y$.

9T: $\quad$...(3) 'ayá'niiłti'go, when he speaks,

10 Raymond Naakai ${ }^{5}$ yatti'í t'áá $<\mathrm{X}$ hai ya-- hai yał-- $\mathrm{X}>$, Raymond Naakai speaking just $<\mathrm{X}$ who sp- who speak-- $\mathrm{X}>$

11 ... Hagooshíi yałti łeh.

He speaks really well usually.

12E:@@@@

13T: ... yizists'ąągo.

3.obj-themat-1p-listen.to-sub

$\rightarrow$... When I listen to him.

14E: shí éí abi'ezaan nizhonigíi baa'i' ií'ah.

Me, I'm voting for the one whose wife is beautiful.

15

[@@@@@@]

16T:_[@@@@@@@]

In this example, the temporal adverbial phrase "yizists'aago (when I listen to him)" (according to Young \& Morgan's (1992) definitive grammar, the subordinating suffix -go on verbs is frequently translated as "when" or "while") is the increment which is added on to the previous, complete turn-constructional unit. In Navajo, a verbfinal language, most intonation units end with a verb, and subordinating morphology is suffixed onto the end of the verb, rather than the beginning of the increment, as in English (i.e., "while, when".)

The next example illustrates another temporal increment:

\section{Example 3}

E is planning to sell some moccasins to a lady friend, so he is going to show some to

\footnotetext{
${ }^{5}$ Raymond Naakai is a well-known Navajo politician.
} 
her.

1E: “t'óó da naashjaah doo" dinoózilitgo.

"just neg themat-1p-have.pair neg." themat-opt.3p-fut.think-sub

"I don't have a pair" she might think.

2 "t'ááłígíi”" didoóniił.

One-partic. Themat-opt-3p.fut.say.

"That one (pair)" she might say.

3T: haishąa

who's that,

$4 \quad$ asdząa nanayiní'íígo?

woman rep-3p-2p-see-sub.

the lady you are seeing (dating)?

5 ...(1)@@@..t'ó adishni <@ shinálí@>.

6E: $\quad$ eeei $=$, I'm just kidding, $<@$ grandpa $^{6} @>$.

$7 \quad$...(1) éí t’áá'aní.

...(1) it's true.

8 .. Asdzáníi łah shich'í dahighaa nt'éé.

woman one to me pl-3p-fit past

.. a woman was interested in me. ( $\mathrm{E}$ is now in a wheelchair)

9T: ... mm.

10E: $\quad \ldots(2)<$ P ahot'élá $\mathrm{P}>$.

... (2) It is/was that way.

11T: $\quad$...(1) nt'éé. ${ }^{7}$

It was.

12E: $\rightarrow \quad$ éí ałkidáą

(a) long time ago,

$13 \rightarrow$ t'aadii highschoolyéędáą. still (in) highschool back then.

14T: oh, nídáhonoosníih ní? 2p.obj-pl-be.popular 2p.say

${ }^{6}$ A kinship term he uses with $\mathrm{E}$.

${ }^{7}$ Navajo past tense is accomplished through this temporal enclitic nt'éé which typically occurs clause finally. In this case, it is somewhat ambiguous in function, but it appears that $\mathrm{T}$ is confirming the past tense of E's previous IU: "ahot'ela" which actually carries no tense of its own. 
oh, you mean someone had a crush on you?

15E: $\quad \mathrm{mmm}$.

16T: $\quad$...(2) díí léí éí nizhoní łeh, this one is pretty nice, ((referring to a coin))

In this example, the increment consists of two separate intonation units (lines 1213) "a long time ago, still (in) high school back then" which are added on to the previous IU "It was that way." The temporal phrase éi atkidáq "a long time ago," is also typically used as a formulaic opening for stories about the distant past, much like the English "long ago, in a place..." The suffix yéędáq ("back then," "in those days") in this case attaches to an English borrowing into Navajo, the noun "high school." This temporal suffix appears at the end of the increment, as opposed to English increments which are frequently initiated with a subordinate marker (Couper-Kuhlen 1996, Ford et al. 2002.)

Example (3) is a little more complicated than the previous two, both in semantic content and its related pragmatics and interaction. For example, it might be argued in this particular example that the increment occurs because T's uptake (ntée "it was") is not perceived as adequate enough by E, who is telling T that “.. Asdzáníi łah shich’í dahighaa nt'éé (a woman was interested in me)" which is somewhat titillating information. How T should be expected to respond to this admission is further clouded by the fact that $\mathrm{E}$ is married, but also in a wheelchair now, and perhaps most importantly that a tape recorder is running. However, T's response should perhaps be considered adequate uptake considering Navajo's typical interactional style. As I will discuss further in the conclusion, I don't believe E is "fishing" for more uptake or assessment here, due to a preference for indirection which is well documented in the ethnographic literature on Apachean interaction (Navajo belonging to the Apachean, or Southern Athabascan, language family.)

The last example I found is somewhat ambiguous in terms of function: it follows a syntactically, prosodically and pragmatically complete turn-constructional unit, and it is something like an "unattached NP" (Ford et al. 2002) which forms a pragmatic unit (a list) with the previous utterance in line 1. It is an example of an increment which is pragmatically, rather than syntactically, dependent on the previous intonation unit. In Couper-Kuhlen and Ono's typology, it is a free constituent following a final intonation contour, recompleting the pragmatic unit. Where the pragmatic unit (the list) previously contained only two items, it is recycled to contain three.

\section{Example 4}

((T \& E are talking about old coins, laid on the table))

1T: éí ałtse' haniidee' bikee dóó índa éí silver.

things-come out

first they (gold ones) appeared before and then the silver ones.

$2 \rightarrow \quad$ k'ad éí díí t'óó federal-reserve note dah bikaa. now these just "federal reserve note" on top (of it). 
3E: $\quad$ mm-mm.

4T: éígo éí t’áá 'ákónéehéę. those.sub deic. just be.right-nom.past ${ }^{8}$. those ones were the real ones.

5E: $\quad<$ LO shido' la nahideeshni LO $>$. Me too I'll buy some (real certificates).

6T: aoo'!

Yes!

7 éígo éí t’áá 'íiyisíí ili'. those-sub deic. just valuable are those ones are the really valuable ones.

Line 2 is more than simply a temporal phrase; it is also an addition to a chronological list (of types of currency issued by the federal government: first gold, then silver, now just dollar bills.) Instead of being grammatically fitted to the previous complete IU (it has no subordinating morphology), it is "pragmatically fitted," and for this reason I believe it still fits the definition of an increment.

\section{Discussion}

To summarize, I found four examples of increments in 20 minutes of conversation. I found 2 temporal adverbial phrases (examples 2 and 3), a locative deictic (example 1), and a noun phrase, which appears to be a pragmatic (rather than syntactic) increment (example 4.) All of these types of increments may also be found in English conversation. I did not find any relative clauses or reason clauses being used as increments ${ }^{9}$.

As for the function which increments in Navajo serve, they work very differently from those in English. For example, they do not appear to be used for eliciting uptake, a common function of English increments (Ford et al. 2002). As three of my examples show (1-3), they occur after immediate responses from the hearer, so they are not due to lack of recipiency. Although some might argue that example 3 reflects a concern on the part of speaker E that listener T's recipiency is not robust enough, it is perfectly suited

${ }^{8}$ Line four in this example illustrates how Navajo uses stative verbs (in this case a nominalized verb) to serve the function of assessment, rather than unattached NPs.

9 Relativized NPs NPs are typically nominalized verbs, which precede main verbs. There are two relative clauses in example (2) above:

a. éi hastiin ábijaah dadikaadigíí baa'itíishaal nisingo.

deic. man his ears pl-stat.flat-rel for-1p-fut.vote themat-1p-think-sub

I'm going to vote for the guy whose ears are big (and) flappy, I think.

b. shi éi abi'ezaan nizhonigíí baa'i'í' aah.

I deic. 3poss-wife is.beautiful-rel for-themat-one.votes

$\mathrm{Me}, \mathrm{I}$ 'm voting for the one the one whose wife is beautiful. 
for Athabascan interaction, which tends toward understatement, indirection and ambiguity, in general. As previous work has repeatedly found, Athabascan interaction typically reflects a cultural value on individual autonomy, which is seen in a healthy respect for allowing current speaker to keep the floor, a value on silence and noninterruption, and avoidance of interpretation of speaker's meaning (Basso 1970, 1979; Saville-Troike 1985; Scollon 1985; Field 1998). These same cultural values are undoubtedly responsible for the fact that none of my examples are assessments, another common function for English increments (Ford et al. 2002) nor do they appear to be functioning as "stance displays" of the speaker's attitude toward their prior utterance, as is suggested for English by Ford et al. (2002). Furthermore, there is no rapid prosody, or what Schegloff (1996: 84) has termed a "rush through" ${ }^{10 "}$ in conjunction with the Navajo increments presented here; rather, as has been frequently observed in Athabascan interaction by various researchers, pause lengths are relatively long, even within turns (Basso 1970; Saville-Troike1985; Scollon 1985; Field 1998.) Although backchanneling or minimal responses are frequent on the part of hearers, there is very little overlap in turns.

Navajo interaction, like Athabascan interaction in general, is typically marked by a salient respect for the autonomy of all participants, and this concern is reflected in pause length, absence of address terms or tag questions (Field 1998), and the avoidance of direct gaze (Guilmet 1978). Considering all of these differences in language use it should not be surprising to find that increments are also used differently in conversation, or that hearers orient to them in a uniquely different way.

Appendix

The transcription system used here is that of Du Bois et al. 1993

for broad transcription, with one exception: in the interest of saving space, some short intonation units are combine on a line:

$\begin{array}{ll}\text { Intonation unit } & <\mathrm{CR}> \\ \text { Truncation } & - \\ \text { Overlap } & {[]} \\ \text { Final intonation } & \cdot \\ \text { Continuing intonation } & , \\ \text { Appeal } & ? \\ \text { Accent } & \wedge \\ \text { Lengthening } & = \\ \text { Timed pause } & \ldots(2)=2 \text { seconds } \\ \text { untimed pause } & \ldots \\ \text { Inhalation } & (\mathrm{H}) \\ \text { Exhalation } & (\mathrm{Hx}) \\ \text { Glottal stop } & \% \\ \text { Laughter } & @\end{array}$

10 Ford \& Thompson (1996: 165) link rush-throughs to increments as one strategy "for avoiding completion even when syntax, intonation and pragmatics conspire to signal it." 


$\begin{array}{ll}\text { Laugh quality } & <@ @> \\ \text { Pianissimo } & <\mathrm{P} \text { P }> \\ \text { Researcher's Comment } & ((\mathrm{)}) \\ \text { Uncertain Hearing } & <\mathrm{X} \mathrm{X}> \\ \text { Indecipherable syllable } & \mathrm{X}\end{array}$

\section{References}

Basso, Keith (1970) "To give up on words," silence in Apache culture. Southwest Journal of Anthropology 26.3: 213-38.

Basso, Keith (1979) Portraits of the Whiteman: Linguistic play andcultural symbolism among the Western Apache. N.Y.: Cambridge University Press.

Couper-Kuhlen, E. (1996) Intonation and clause-combining in discourse: The case of because. Pragmatics 6.3: 389-426.

Couper-Kuhlen, E., \& T. Ono (this volume) "Incrementing” in conversation: A comparison of practices in English, German and Japanese.

Du Bois, John, Stephan Schuetze-Coburn, Danae Paolino, and Susanna Cumming (1993) Outline of discourse transcription. In Jane A. Edwards and Martin D. Lampert (eds.), Talking data: Transcription and coding methods for language research. Hillsdale, NJ: Lawrence Erlbaum, pp. 45-89.

Field, M. (1998) Maintenance of indigenous ways of speaking despite language shift: Language socialization in a Navajo preschool. Dissertation, UCSB Linguistics.

Field, M. (1998) Politeness and indirection in Navajo directives. Journal of Southwest Linguistics 17.2: 23-34.

Ford, C., \& S. Thompson (1996) Interactional units in conversation: Syntactic, intonational, and pragmatic resources for turn management. In Elinor Ochs, Emanuel Schegloff, and Sandra Thompson (eds.), Interaction and grammar. Cambridge: Cambridge University Press, pp. 134-184.

Ford, C., B. Fox, \& S.A. Thompson (eds.) (2002) The language of turn and sequence. Oxford: Oxford University Press.

Guilmet, G. (1978) Navajo and Caucasian children's verbal and nonverbal visual behavior in the urban classroom. Anthropology and education quarterly 9: 196-215.

Saville-Troike, Muriel (1985) The place of silence in an integrated theory of communication. D. Tannen, \& M. Saville-Troike (eds.), Perspectives on silence, pp.. 3-18.

Schegloff, E. (1996) Turn organization: one intersection of grammar and interaction. In Elinor Ochs, Emanuel Schegloff, and Sandra Thompson (eds.), Interaction and grammar. Cambridge: Cambridge University Press, pp. 134-184.

Schegloff, E. (2000) Overlapping talk and the organization of turn-taking for conversation. Language in society. 29: 1-63.

Scollon, Ron. (1985) The machine stops: silence in the metaphor of malfunction. In D. Tannen, \& M. Saville-Troike (eds.), Perspectives on silence. Norwood, NJ: Ablex, pp. 21-31. 


\section{Margaret Field}

Young, Robert., William Morgan, and Sally Midgette (1992) Analytical lexicon of Navajo.Albuquerque: University New Mexico Press. 